OPEN ACCESS

Edited and Reviewed by: Ashok Mysore,

St. John's Medical College, India

*Correspondence:

Dulce María Romero-Ayuso drayuso@gmail.com

Specialty section:

This article was submitted to Child and Adolescent Psychiatry, a section of the journal Frontiers in Pediatrics

Received: 18 September 2017 Accepted: 28 November 2017 Published: 12 December 2017

Citation:

Jorquera-Cabrera S, RomeroAyuso DM, Rodriguez-Gil G and

Triviño-Juárez J-M (2017)

Corrigendum: Assessment of Sensory Processing Characteristics

in Children between 3 and 11 Years Old: A Systematic Review. Front. Pediatr. 5:266. doi: 10.3389/fped.2017.00266

\section{Corrigendum: Assessment of Sensory Processing Characteristics in Children between 3 and 11 Years Old: A Systematic Review}

\author{
Sara Jorquera-Cabrera ${ }^{1}$, Dulce María Romero-Ayuso ${ }^{2,3 *}$, Gemma Rodriguez-Gil ${ }^{2}$ \\ and José-Matías Triviño-Juárez ${ }^{4}$ \\ ${ }^{1}$ Centro de Terapia Infantil AYTONA, Madrid, Spain, ${ }^{2}$ Facultad de Terapia Ocupacional, Logopedia y Enfermería, Psychology, \\ Universidad de Castilla-La Mancha, Talavera de la Reina, Spain, ${ }^{3}$ Facultad de Ciencias de la Salud, Departamento de \\ Fisioterapia, Universidad de Granada, Granada, Spain, ${ }^{4}$ West Health District, Primary Care Center Francia, Madrid Health \\ Service, Madrid, Spain
}

Keywords: assessment, children, sensory integration, sensorial modulation, sensory processing

\section{A corrigendum on}

Assessment of Sensory Processing Characteristics in Children between 3 and 11 Years Old: A Systematic Review

by Jorquera-Cabrera S, Romero-Ayuso D, Rodriguez-Gil G, Triviño-Juárez J-M. Front Pediatr (2017) 5:57. doi: 10.3389/fped.2017.00057

\section{Error in Figure/Table}

In the original article, there was a mistake in Table 2 "Tools selected for the assessment of sensory processing in children aged 3 to 11 years". We want to clarify that the errors we have corrected in this document occurred when transcribing the data. We want to clarify that these errors have not been intentioned

The corrected Table 2 appears below. The authors apologize for this error and state that this does not change the scientific conclusions of the article in any way.

The original article has been updated. 


\section{Sensory To assess sensory} processing processing, praxis and

measure (SPM) social participation

(52) in different school

environments and at

home
SPM (5-12 years): The scale is completed by teachers and home form, main caregivers who have known the child for classroom form, and more than a month

school environments

form. SPM-P

( $2-5$ years) home

and school forms
SPM was standardized with a sample of 1.051 typically developing children from the USA and Canada, aged therapy treatment was used to verify that SPM could help us differentiate typical children from those with clinical disorders. SPM-P was standardized with 651 typically developing

children from the USA aged 2-5 years. Also, a sample of 242 children with occupational therapy treatment was used to verify that SPM-P let us differentiate typical children from those with clinical disorders. Good reliability and validity. Internal consistency (alpha coefficient) $\geq 0.75$ for all scales and forms. SPM scales appropriately distinguished between a normative sample and a sample of clinic-referred children with sensory processing difficulties Sensory profile Evaluates the type of Different versions. It Scale is completed by teachers and parents responses and selfDifferent versions. It
can be administered regulation strategies used from 0 to 14 years. by the child and the type There is a second of neurological threshold for different sensory version $\left(\mathrm{SP}^{2}\right)$ toddler stimuli form (SSP) and school companion published in 2014 children without disabilities, 32 children with autism and 6 with ADHD diagnosis. New version of Sensory profile, Sensory Profile 2 was standardized with a sample of 1,376 school-age children in the USA $5-13$ years. Also, 345 children receiving occupational

\section{psychometric scores}

Sensory Processing Measure-

Hong Kong Chinese version (SPMHKC). Cronbach's alpha 0.80. ICC of the Main classroom form ranged from 0.82 to 0.98 and the ICC of the home form ranged from 0.70 to 0.95 . Good discriminant validity. Moderate correlation between Sensory profile Chinese and SPM-HKC. It is available in Danish, Finnish, Norwegian, Swedish, and Arabic

Infant/toddler sensory profile. ICC > 0.90. Alpha coefficients

retest reliability $=0.81-0.90$

India Sensory Profile Caregivers Questionnaire The interrater reliability $(I C C=0.87)$, test-retest reliability $(I C C=0.90)$, internal consistency (Cronbach's $\alpha=0.86$ ) section total correlation, face, and content validity for the SPCQ were good. A threshold score of $\leq 481$ in SPCQ was considered ideal as a cutoff score to identify cases of sensory processing dysfunction among Indian children. Sensory Profile for Chinese children with a good internal consistency (Cronbach's $\alpha=0.82$ ). Test-retest reliability over a 2-week period $(r=0.93)$

$\mathrm{ICC}=0.80-0.90$ good test-retest reliability across quadrants, for factors $I C C=0.69-0.88$ years $I C C=0.50-0.87$ for scores in the composites of sensory processing, modulation, and behavioral and emotional responses. Internal consistency of the sections ranges from 0.70 to 0.90

SSP has a discriminant validity of $>95 \%$ in identifying children with and without sensory processing differences 
TABLE 2 | Continued

\begin{tabular}{|c|c|c|c|c|c|}
\hline Tool & Objective & Population & Applicability & Psychometric properties & $\begin{array}{l}\text { Language in which the } \\
\text { tests are available and the } \\
\text { psychometric scores }\end{array}$ \\
\hline $\begin{array}{l}\text { Sensory } \\
\text { Integration and } \\
\text { Praxis Test } \\
\text { (SIPT) (6) }\end{array}$ & $\begin{array}{l}\text { To assess children's } \\
\text { sensory integration and } \\
\text { praxis problems }\end{array}$ & $\begin{array}{l}\text { Children aged } \\
\text { from } 4 \text { to } 8 \text { years } \\
11 \text { months }\end{array}$ & $\begin{array}{l}\text { Comprises } 17 \text { tests. Administered } \\
\text { using visual demonstration and spoken } \\
\text { instructions, except when assessing praxis. } \\
\text { The lower the score, the greater the difficulty }\end{array}$ & $\begin{array}{l}\text { Standardized with a sample of } 1997 \text { children in the USA. High } \\
\text { psychometric properties }\end{array}$ & $\begin{array}{l}\text { Available only in English, for USA } \\
\text { population }\end{array}$ \\
\hline $\begin{array}{l}\text { DeGangi-Berk } \\
\text { Test of Sensory } \\
\text { Integration (TSI) } \\
\text { (58) }\end{array}$ & $\begin{array}{l}\text { Conducts a screening } \\
\text { of SI dysfunction, } \\
\text { with emphasis on the } \\
\text { vestibular system. } \\
\text { Assessment of postural } \\
\text { and components and } \\
\text { praxis. It is based } \\
\text { on Assessment of } \\
\text { Sensorimotor Integration } \\
\text { in Preschool Children } \\
\text { (DeGangi, 1979) (66) }\end{array}$ & $\begin{array}{l}\text { Infant population } \\
\text { aged 3-5 years }\end{array}$ & $\begin{array}{l}\text { Comprises } 36 \text { items and assesses posture } \\
\text { control, bilateral motor integration and reflex } \\
\text { integration. The child completes various } \\
\text { tests. Administration time is } 30 \mathrm{~min}\end{array}$ & $\begin{array}{l}\text { Validity of domain and construct, stable inter-observer } 0.84 \\
\text { and test-retest reliability. Standardized with a sample of } 101 \\
\text { typical children and } 38 \text { developmental delayed children from } \\
\text { US population }\end{array}$ & Available only in English \\
\hline $\begin{array}{l}\text { Touch Inventory } \\
\text { for elementary } \\
\text { school-aged } \\
\text { children (TIE) } \\
\text { (61) }\end{array}$ & $\begin{array}{l}\text { Measures tactile } \\
\text { defensiveness }\end{array}$ & $\begin{array}{l}\text { Population } \\
6-12 \text { years. } \\
\text { The criteria for } \\
\text { administration are } \\
\text { that the child needs } \\
\text { to have the language } \\
\text { competence of at } \\
\text { least a 6-year-old, } \\
\text { an IQ of at least } 80 \\
\text { and no presence of } \\
\text { physical disabilities } \\
\text { (Royeen and Fortune } \\
\text { 1990) }\end{array}$ & $\begin{array}{l}\text { The } 26 \text {-item Questionnaire. The response } \\
\text { format for the TIE is } 1=\text { no, } 2=\text { a little, } \\
\text { and } 3=\text { a lot. Administered in } 15 \text { min, } \\
\text { self-reported by child. The higher the score, } \\
\text { the more the self-reported behaviors are } \\
\text { indicative of tactile defensiveness }\end{array}$ & $\begin{array}{l}\text { Standarized with a sample of } 415 \text { children from USA. Test - } \\
\text { retest reliability }(r=0.91) \text { with } 1 \text {-week testing interval }\end{array}$ & Available only in English \\
\hline $\begin{array}{l}\text { Sensorimotor } \\
\text { clinical } \\
\text { observations } \\
\text { (63-66) }\end{array}$ & $\begin{array}{l}\text { Provides information } \\
\text { on vestibular and } \\
\text { proprioceptive functions. } \\
\text { Mainly used to diagnose } \\
\text { motor planning problems, } \\
\text { vestibular, proprioceptive, } \\
\text { proprioceptive-vestibular } \\
\text { and motor deficits }\end{array}$ & From age 5 & $\begin{array}{l}\text { A tool that requires training and practice to } \\
\text { be correctly administered and interpreted. } \\
\text { Comprises } 15 \text { tests. Administration time } \\
\text { between } 30 \text { and } 40 \text { min }\end{array}$ & $\begin{array}{l}\text { High interrater reliability. Discriminative validity measured with a } \\
\text { sample of children in Chile and the USA } p<0.01 \text {. Portuguese } \\
\text { transcultural adaptation study }(N=201)\end{array}$ & Available in English and Spanish \\
\hline $\begin{array}{l}\text { Comprehensive } \\
\text { Observations of } \\
\text { Proprioception } \\
\text { (COP) (67) }\end{array}$ & $\begin{array}{l}\text { The COP provides a } \\
\text { reliable measure for } \\
\text { detecting the origin of } \\
\text { proprioceptive problems } \\
\text { affecting children's } \\
\text { functional performance }\end{array}$ & $\begin{array}{l}\text { Infant population } \\
\text { from } 2 \text { years of age }\end{array}$ & $\begin{array}{l}\text { Takes } 15 \text { min to administer and is designed } \\
\text { for use in conjunction with sensorimotor } \\
\text { observations or while observing a child's } \\
\text { free play }\end{array}$ & $\begin{array}{l}\text { Sample size was } 130 \text { children. Intraclass correlation coefficient } \\
\text { was } 0.91 \text {. Validity found between results of COP and items } \\
\text { from the SPM (body awareness) and the KIN (kinesthesia) and } \\
\text { SWB (Standing and Walking Balance) tests from the SIPT }\end{array}$ & Available in English and Spanish \\
\hline
\end{tabular}


TABLE 2 | Continued

\begin{tabular}{|c|c|c|c|c|c|}
\hline Tool & Objective & Population & Applicability & Psychometric properties & $\begin{array}{l}\text { Language in which the } \\
\text { tests are available and the } \\
\text { psychometric scores }\end{array}$ \\
\hline $\begin{array}{l}\text { The Miller } \\
\text { Assessment for } \\
\text { Preschoolers } \\
\text { (MAP) (68) }\end{array}$ & $\begin{array}{l}\text { Assesses a child's } \\
\text { attention, social } \\
\text { interaction, and sensory } \\
\text { reactivity during the } \\
\text { testing procedure } \\
\text { provides a profile of } \\
\text { sensory discrimination } \\
\text { abilities, postural } \\
\text { foundations, and praxis } \\
\text { and screens for visual, } \\
\text { perceptual, and language } \\
\text { delays that could be } \\
\text { affecting participation in } \\
\text { the classroom }\end{array}$ & $\begin{array}{l}\text { Test for children } \\
\text { from } 2 \text { years, } \\
9 \text { months to } 5 \text { years, } \\
8 \text { months of age }\end{array}$ & $\begin{array}{l}\text { Administration time } 30 \text { min. There are two } \\
\text { forms: MAP Screening } 27 \text { Core test items } \\
\text { (evaluation of attention, social interaction } \\
\text { and sensory reactivity) and MAP Extended } \\
\text { (behavior during testing, supplemental } \\
\text { observations, developmental history: } \\
\text { speech language, movement, draw a } \\
\text { person), development history. } 27 \text { subtests } \\
\text { in } 5 \text { domains: neurological foundations, } \\
\text { motorcoordination, language, nonverbal } \\
\text { cognition, and complex tasks (combined } \\
\text { domains). The total MAP score is expressed } \\
\text { in percentiles, and the cut-points are 0\% to } \\
5 \% \text { (Red; likely problem, refer for evaluation), } \\
6 \% \text { to } 25 \% \text { (Yellow; possible problem, watch } \\
\text { carefully and use clinical judgment about } \\
\text { the need to refer for evaluation), and } 26 \% \text { to } \\
99 \% \text { (Green; unlikely to have problems, do } \\
\text { not refer for assessment) }\end{array}$ & $\begin{array}{l}\text { The MAP was standardized with a sample of } 1,014 \text { children. } \\
\text { The MAP has excellent internal reliability }(r=0.79-0.82) \text { and } \\
\text { interrater reliability }(r=0.98) \text {. Test-retest reliability for total } \\
\text { score is } r=0.81 \text { Content validity for the MAP is supported } \\
\text { in the literature as MAP total score correlates significantly } \\
\text { with the WISC-R IQ scale }(r=0.50-0.45) \text { and with the } \\
\text { Woodcock-Johnson Math, Reading and Language subtests } \\
(r=0.38-0.35)\end{array}$ & $\begin{array}{l}\text { Available in English, Japanese and } \\
\text { Hebrew }\end{array}$ \\
\hline $\begin{array}{l}\text { Sensory } \\
\text { Experiences } \\
\text { Questionnaire } \\
\text { Version } 3.0 \\
\text { (SEQ-3.0) } \\
(7,69-72)\end{array}$ & $\begin{array}{l}\text { To obtain sensory } \\
\text { characteristics and } \\
\text { discriminate sensory } \\
\text { patterns of hypo- and } \\
\text { hyper-responsiveness } \\
\text { among persons with } \\
\text { autism, mental or } \\
\text { developmental retardation }\end{array}$ & For 2-12 years & $\begin{array}{l}\text { It is a } 105 \text {-item parent report tool designed } \\
\text { specifically to measure behavioral responses } \\
\text { to naturally occurring sensory stimuli } \\
\text { in the context of everyday situations in } \\
\text { children with ASD. SEQ measures the } \\
\text { frequency of sensory behaviors across } \\
\text { four sensory response patterns (hypo- } \\
\text { responsiveness, hyper-responsiveness, } \\
\text { sensory interests, repetitions and seeking } \\
\text { behaviors and enhanced perception), five } \\
\text { modality categories (i.e., auditory, visual, } \\
\text { tactile, gustatory/olfactory, vestibular/ } \\
\text { proprioceptive), and two contexts (i.e., social } \\
\text { and non-social). The first } 97 \text { items measure } \\
\text { the frequency using a } 5 \text {-point Likert scale } \\
\text { ranging from } 1 \text { (never/almost never) to } \\
5 \text { (always/almost always) with a higher } \\
\text { score indicating more sensory symptoms. } \\
\text { Caregiver takes approximately } 15-20 \text { min to } \\
\text { complete the questionnaire }\end{array}$ & $\begin{array}{l}\text { Has good internal consistency and test-retest reliability. Useful } \\
\text { for assessing children with ASD. Psychometric study was } \\
\text { conducted with } 358 \text { caregivers }\end{array}$ & Available only in English \\
\hline
\end{tabular}




\begin{tabular}{|c|c|c|c|c|c|}
\hline Tool & Objective & Population & Applicability & Psychometric properties & $\begin{array}{l}\text { Language in which the } \\
\text { tests are available and the } \\
\text { psychometric scores }\end{array}$ \\
\hline $\begin{array}{l}\text { The Sensory } \\
\text { Processing } \\
\text { Scales (SPS) } \\
\text { Version } 2.0 \text { (28) }\end{array}$ & $\begin{array}{l}\text { Evaluates sensory } \\
\text { reactivity in seven } \\
\text { domains: tactile (self- } \\
\text { care and materials), } \\
\text { auditory (sounds } \\
\text { and places), visual, } \\
\text { olfactory, gustatory, and } \\
\text { vestibular-proprioception }\end{array}$ & $4-19$ & $\begin{array}{l}\text { Consists of a performance assessment } \\
\text { of different activities and a caregiver- } \\
\text { report inventory and a self-report form for } \\
\text { adults. The results propose classifications } \\
\text { of sensory over responsivity, sensory } \\
\text { under responsivity, and sensory seeking. } \\
\text { Administered in approximately } 1 \mathrm{~h} \text {. Consists } \\
\text { of } 27 \text { subtests and } 72 \text { items across seven } \\
\text { sensory domains (visual, auditory, tactile, } \\
\text { vestibular, proprioceptive, gustatory, and } \\
\text { olfactory). The activities are designed to } \\
\text { resemble sensory experiences in daily life } \\
\text { that generate atypical behavioral responses } \\
\text { in children with sensory problems. Items } \\
\text { within each subtest are scored to reflect the } \\
\text { person's responses at three time periods: } \\
\text { (1) during the activity, (2) after the activity } \\
\text { (<15 s), and (3) during the transition to the } \\
\text { next activity }\end{array}$ & $\begin{array}{l}\text { Standarized sample of } 128 \text { participants. Internal consistency is } \\
\text { moderate to high, interrater reliability is moderate, and internal } \\
\text { validity is statistically significant. Overall internal consistency } \\
\text { yielded a } 0.94 \text {, and domain reliabilities ranged from } 0.79 \\
\text { to } 0.93 \text { (internal reliability }>0.4 \text { ) and discriminant validity } \\
(p<0.01 \text { ). The SPS Assessment appears to be a reliable and } \\
\text { valid measure of sensory modulation (scale reliability }>0.90 \text {; } \\
\text { discrimination between group effect sizes }>1.00 \text { ). This scale } \\
\text { has the potential to aid in differential diagnosis of sensory } \\
\text { modulation issues }\end{array}$ & English \\
\hline $\begin{array}{l}\text { Test of } \\
\text { Ideational Praxis } \\
(\mathrm{TIP})(73)\end{array}$ & $\begin{array}{l}\text { To examine a child's } \\
\text { ability to recognize and } \\
\text { to interact with an and } \\
\text { to evaluate ideation as a } \\
\text { component of praxis }\end{array}$ & $\begin{array}{l}\text { From } 5 \text { to } 8 \text { years. } \\
\text { There is also } \\
\text { a version for } \\
\text { preschoolers, } \\
\text { elaborated in } 2014\end{array}$ & $\begin{array}{l}\text { A child is given a 24-inch long shoelace } \\
\text { and is given the instruction, "Show me } \\
\text { everything you can do with this string" and } \\
\text { is then given } 5 \text { min to demonstrate the } \\
\text { actions. A point is given for each action } \\
\text { but the action must be demonstrated; } \\
\text { description alone is not enough }\end{array}$ & $\begin{array}{l}\text { Studies conducted in } 2014 \text { with } 78 \text { children aged } 3,4 \text {, and } \\
5 \text { years found, after } 2 \text { weeks, that the TIP had a high interrater } \\
\text { reliability of } 0.94 \text { and a good test-retest reliability of } 0.80\end{array}$ & English \\
\hline $\begin{array}{l}\text { Motor } \\
\text { Planning Maze } \\
\text { Assessment } \\
\text { (MPMA) (73) }\end{array}$ & $\begin{array}{l}\text { To be used as a screening } \\
\text { tool to identify deficits } \\
\text { in motor performance } \\
\text { and planning aspect of } \\
\text { dyspraxia }\end{array}$ & $\begin{array}{l}\text { Preschoolers from } 3 \\
\text { to } 5 \text { years }\end{array}$ & $\begin{array}{l}\text { Individually administered test consisting of } \\
\text { three mazes. Application and correction } \\
\text { takes } 5 \text { min }\end{array}$ & $\begin{array}{l}\text { Has only been administered to } 80 \text { children in the USA. } \\
\text { Interrater reliability was excellent on the total MPMA score } \\
\text { [interclass correlation coefficient (0.96) and individual maze } \\
\text { scores }(0.90-0.98) \text {. The total MPMA score can distinguish } \\
\text { developmental differences among preschoolers ages } 3,4 \text {, and } \\
5 \text { years. No differences were observed according to gender, } \\
\text { race, or educational approach }\end{array}$ & English \\
\hline $\begin{array}{l}\text { Pediatric Clinical } \\
\text { Test of Sensory } \\
\text { Interaction for } \\
\text { Balance (CTSIB) } \\
\text { (74) }\end{array}$ & $\begin{array}{l}\text { To evaluate a child's } \\
\text { ability to use visual, } \\
\text { somatosensory, and } \\
\text { vestibular input to } \\
\text { maintain balance while } \\
\text { standing }\end{array}$ & Over 6 years of age & $\begin{array}{l}\text { The child must complete six tests, three on } \\
\text { a stable surface and three on an unstable } \\
\text { one. Some of the tests are performed with } \\
\text { eyes closed and others with eyes open. In } \\
\text { all conditions, the objective is to maintain } \\
\text { balance for at least } 30 \mathrm{~s} \text {. Administration time } \\
\text { is approximately } 20 \mathrm{~min}\end{array}$ & $\begin{array}{l}\text { A tool with excellent interrater reliability }(r=0.88 \text {, range } 0.60- \\
1.00) \text { for children between } 4 \text { and } 9 \text { years old. The sample data } \\
\text { was } 24 \text { typical children. Validity of criteria: with proprioceptive } \\
\text { disorders and the SOT. CTSIB shows which children have } \\
\text { more modulation disorders and more reduced postural control } \\
\text { than typically developing children for all visual stimuli }(p<0.05) \text {, } \\
\text { except for somatosensory input with vision. There are only data } \\
\text { from studies conducted in the USA. There is also a version for } \\
\text { adults and older children }\end{array}$ & English \\
\hline
\end{tabular}


TABLE 2 | Continued

Objective

Population

Applicability

Psychometric properties

Language in which the

tests are available and the

psychometric scores

Classroom

Promote therapist-

Elementary schoo

161 items divided into sections by sensory

type: vision (47), hearing (50), touch (20),

Classroom data $(N=152)$ were analyzed with counts,

English

Sensory

teacher collaboratio

aged

movement (vestibular and proprioceptive;

frequencies, means, and SDs. Reliability was examined with

Assessment to provide student

25), smell (15), and taste (4). Items for the

cafeteria, recess, and playground were

modification, for research

on the impact of the

sensory environment for

children with ASD

included. The teachers rated items on the

basis of a typical week. Teachers rated the

frequency of occurrence of the sensory

experience as no, never, or not applicable;

rarely; occasionally; sometimes; and always.

Next, if applicable, the teachers rated

the intensity of the experience as weak,

internal consistency ratings using Cronbach's alpha. Skew and

kurtosis were examined using the Kolmogorov-Smirnov test

of normality and histogram. Interrater reliability was analyzed

with intraclass correlation coefficients. The tool's internal

consistency is acceptable. Interrater reliability values did not

reach acceptable levels in the pilot using the teacher-therapist

rating pairs and total score. The ICC was -0.197 . Cronbach's

alpha $=0.94$. The current phase (Phase 4) included

collection of descriptive data from a variety of elementary moderate, or strong

classrooms using the current version of the CSEA and an initia investigation of its internal consistency

Preschool The purpose of th

$1.5-4.9$ years

40 PIPS items ar

Psychometric study was conducted with 119 typically

English

PIPS: six gestural, three procedural and one developing children. They demonstrated acceptable intra- and

Praxis Scale and Praxis Scale

(PIPS) $(77,78) \quad$ (PIPS) is designated

to be a reliab

facial. The positive and strong associations

interrater reliability at the item level $(0.45-1.00)$ and scale level.

ween the PIPS scale score and scores

Exploratory factor analysis disclosed four dimensions on the

on mental, language and motor measures

valid multidimensional

in children with autism spectrum disorders

scale: goal directed versus non-goal directed, procedural

instrument to measure

supported criterion-related validity

imitation, and single versus sequential bodily imitation. Internal consistency for the PIPS scale $(a=0.97)$ and subscales was high (a ranged from 0.79 to 0.96 ). In both samples, the PIPS scale score was strongly related to age $(r=0.78$, respectively,

performance of preschoo

$r=0.56)$. Significant relationships between the PIPS score and mental, language, motor ages in the ASD sample supported criterion-related validity ( $r$ ranged from 0.59 to 0.74 ) 
Conflict of Interest Statement: The authors declare that the research was conducted in the absence of any commercial or financial relationships that could be construed as a potential conflict of interest.

Copyright (C) 2017 Jorquera-Cabrera, Romero-Ayuso, Rodriguez-Gil and TriviñoJuárez. This is an open-access article distributed under the terms of the Creative
Commons Attribution License (CC BY). The use, distribution or reproduction in other forums is permitted, provided the original author(s) or licensor are credited and that the original publication in this journal is cited, in accordance with accepted academic practice. No use, distribution or reproduction is permitted which does not comply with these terms. 